\title{
Serological report of influenza a (H7N9) infections among pigs in Southern China
}

\author{
Pei Zhou ${ }^{1 \dagger}$, Malin Hong ${ }^{1 \dagger}$, Mary M Merrill ${ }^{2}$, Huamei He${ }^{1}$, Lingshuang Sun ${ }^{1}$ and Guihong Zhang ${ }^{1 *}$
}

\begin{abstract}
Background: In 2013, a novel H7N9 avian influenza virus (AIV) was isolated from ill humans in Shanghai and Anhui Province, China. Since then, the virus has spread quickly throughout China. Previous isolation of H7N2 virus from swine suggests that additional H7 subtype Alvs may be transmitted through pigs. However, prior to the recent zoonosis of $\mathrm{H7N}$, there were very few studies on the seroprevalence of the $\mathrm{H} 7$ subtypes in this species. Thus, there is a need to perform serological surveys for novel H7N9 as well as other H7 subtype AlVs in swine. This surveillance may help us understand risk factors for outbreaks of influenza A (H7N9) virus.

Results: Only 2.0\% (26/1310) of the pig sera had antibodies with an $\mathrm{HI}$ titer $\geq 1: 20$, and none had an MN titer $\geq 1: 80$, against the $\mathrm{H} 7$ antigen. Thus, no samples were found to be positive against H7N9. However, $13.6 \%(178 / 1310)$ of the pig sera had antibodies with $\mathrm{HI}$ titer $\geq 1: 20$ and $8.5 \%$ (112/1310) by MN titer $\geq 1: 80$ against $\mathrm{H} 9$ antigen. Thirty-seven percent (484/1310) of the pig sera had antibodies with $\mathrm{HI}$ titer $\geq 1: 20$ and $18.2 \%$ (238/1310) had MN titer $\geq 1: 80$ against pandemic 2009 .

Conclusions: Pigs in southern China have been shown to be infected with multiple avian influenza viruses. As the prevalence of novel influenza A viruses (e.g., H7N9 avian influenza virus) may be increasing among poultry in China, similar seroepidemiological studies of pigs should be conducted in the future.
\end{abstract}

Keywords: H7N9, AIV, Pig

\section{Background}

Among the 17 hemagglutinin (HA) subtype viruses detected among domestic birds, wild birds and bats, H7 subtypes have occasionally infected humans and generated significant public health concerns. In 2013, a novel H7N9 avian influenza virus (AIV) was isolated from ill humans in Shanghai and Anhui Province, China [1]. Since then, the virus has spread quickly throughout the country. As of August 11, 2013, a total of 134 human H7N9 infections (45 deaths) in China had been reported to the World Health Organization (WHO) [2]. Recent research has shown that the novel H7N9 AIV may be transmissible between mammals (ferrets) [3,4]. The H7N9 AIV has also been isolated from one retail pork worker in Shanghai. H7N9 zoonosis was not preceded

\footnotetext{
* Correspondence: guihongzh@scau.edu.cn

${ }^{\dagger}$ Equal contributors

'Key Laboratory of Animal Disease Control and Prevention of the Ministry of Agriculture, College of Veterinary Medicine, South China Agricultural University, 483 Wushan Road, Tianhe District, Guangzhou 510642, China Full list of author information is available at the end of the article
}

by overt epizootics in domestic poultry or other avian species in the wild, and the source of human infection remains to be definitively established [5]. In response to the reported human infections with H7N9 virus, the Ministry of Agriculture of the People's Republic of China expanded and enhanced surveillance in live bird markets and poultry farms, as well as in swine farms and slaughterhouses, across the whole country, particularly in the affected region and surrounding provinces of southern China. Within six weeks of the initial case report, testing of tens of thousands of samples from poultry and their environment resulted in the identification of 51 H7N9 virus isolates from the provinces of Anhui, Guangdong, Zhejiang, Fujian, and Jiangsu, as well as the Shanghai municipality, mostly from live poultry markets [6]. For multiple reasons, it seems biologically plausible that pigs could be involved in the ecology of this emergent H7N9 virus in southern China. Some large-scale swine farms are adjacent to lakes that are home to multiple species of wild birds. In southern China, many farms raise pigs and poultry in close proximity. Recently, avian-origin 
H7N2 influenza viruses have been isolated from pigs in South Korea [7]. The isolation of swine H7N2 virus suggests zoonotic significance, highlighting the probable transmission of $\mathrm{H} 7$ subtype AIVs through pigs and prompting us to perform surveillance in this species. Prior to the recent zoonosis of H7N9, there were very few studies on the seroprevalence of the $\mathrm{H} 7$ subtypes in pigs. Serologic surveys are urgently needed to help us understand outbreaks of influenza A (H7N9) virus. Thus, we conducted surveillance from January 2011 to November 2012 in the Jiangsu, Zhejiang, Guangdong and Fujian Provinces in eastern China to evaluate whether pigs were infected with the novel H7N9 virus.

\section{Methods}

Swine farms in southern China vary in size from largescale farms (>3000 pigs raised per year) to backyard farms ( $<100$ pigs raised per year). Farms often raise pigs indoors, have little biosafety and seldom use swine influenza vaccines. Many pigs on swine farms have contact with wild birds or domestic poultry. We worked with local veterinary department leaders who regularly inspect swine farms in Jiangsu, Zhejiang, Guangdong and Fujian Provinces of southern China, where novel H7N9 AIV are currently circulating or were frequently detected in 2013. For inclusion in the study, we selected swine farms by location (to generate a geographically balanced sample of farms), and we studied only pigs on large-scale farms that denied having a swine influenza vaccine program. Pigs were selected using a stratified random sampling method. Three groups of pigs were selected from each farm: weaning pigs, finishing pigs, and sows. No anesthesia was used during phlebotomy. All the owners of the swine farms gave permission for their animals to be sampled in this study. Pigs were restrained by rope or wire loop while a health professional performed the 4.0-5.0 mL serum draw. Our sampling processes were assisted by local authorities and licensed veterinarians. The animal research in this study protocol was reviewed and approved by the Guangdong Center for Disease Control and Prevention.

As reported in previous studies [8], we employed a hemagglutination inhibition (HI) assay according to the WHO's protocol. An H7 antigen (A/Guangdong/GH074/ 2013 (H7N9)) derived from the emergent H7N9 AIV was obtained from the College of Veterinary Medicine, South China Agricultural University. Negative control serum (pig serum) and positive control (mice serum) were also prepared by the College of Veterinary Medicine, South China Agricultural University. All serum samples were treated with a receptor-destroying enzyme [RDE, prepared by China National Influenza Center (CNIC)] and absorbed with erythrocytes to remove nonspecific inhibitors before use in the assays. Briefly, two-fold serial dilutions of serum samples were added to $\mathrm{V}$-shaped micro titer plates, and 4
HA units of virus were added to each well. The mixture was incubated at room temperature for 35 minutes. Then, $1 \%(\mathrm{v} / \mathrm{v})$ horse erythrocytes were added in each well. The plates were left at room temperature for 40 minutes. The HI titers were expressed as the highest dilution of serum producing complete inhibition of agglutination. All positive control serum specimens had HI titers of 1:20 or more. We isolated the other AIV antigens used in this study: low pathogenic avian influenza viruses (LPAIV) A/chicken/Guangdong/V/2008 (H9N2), at the College of Veterinary Medicine, South China Agricultural University. The LPAIV A/chicken/Guangdong/V/ 2008 (H9N2), Beijing/1/94-like, was selected for a control as it is the most prevalent subtype of influenza virus in poultry in China [9]. The antigens A/California/7/ 2009pandemic (H1N1) 2009 virus, recently circulating among pigs in China, was also used for HI testing. Negative control serum and positive control serum specimens from different species were included in each plate to provide a full range of controls. Sera from pigs that were $\mathrm{HI}$ titer $\geq 20$ by horse-RBC HI assay were confirmed with a microneutralization assay $(\mathrm{MN})$ procedure recommended by the WHO [10]. Both the HI titer $\geq 1: 20$ and MN titer $\geq$ 1:80 were considered as positive evidence of previous H7N9 infection.

\section{Results}

During the period between January 2011 and November 2012, we drew blood from a total of 1310 pigs from 120 farms in Jiangsu, Zhejiang, Guangdong and Fujian Provinces of southern China. These 4 provinces have had numerous recent detections of H7N9. A total of 172 of the 1310 pigs had clinical signs of influenza-like infection (cough, sneezing or heavy nasal mucus). The results from the 1310 pig blood samples were obtained by $\mathrm{HI}$ assay and $\mathrm{MN}$ assay. $\mathrm{HI}$ titers of $\geq 1: 20$ were detected in 178 of the 1310 serum samples using the H9N2 AIV antigens. Only 26 of the 1310 samples had HI titers of $\geq 1: 20(2 / 26$ with $\mathrm{HI}$ titer $=1: 40)$ using the H7N9 AIV antigens. Although 112 of the 178 H9N2 AIV HIpositive samples were also positive by the $\mathrm{MN}$ assay (MN titer $\geq 1: 80$ ), none of the 26 H7N9 AIV HI-positive samples were positive by the MN assay ( $M N$ titer $\geq 1: 80$ ), revealing that no samples were positive for $\mathrm{H} 7 \mathrm{~N} 9$. As a control, $37.0 \%(484 / 1310)$ of sera were found positive by $\mathrm{HI}$ assay ( $\mathrm{HI}$ titer $\geq 1: 20$ ) for $\mathrm{H} 1 \mathrm{~N} 1$ pdm09, and $18.2 \%$ (238/484) of these HI-positive samples were also positive by the $\mathrm{MN}$ assay (MN titer $\geq 1: 80$ ) (Table 1 ).

None of the four provinces studied had statistically significant different rates of swine infection with avian influenza virus. However, by $\mathrm{HI}$ assay, samples from 2012 showed an increased risk of elevated antibodies against avian influenza virus H7N9 as compared to samples from 2011. Sows had a significant increased risk of 
Table 1 Characteristics an influenza serological assay results of pigs sampled with serum specimen collections, January 2011 to November 2012

\begin{tabular}{|c|c|c|c|c|c|c|c|c|c|}
\hline \multirow[t]{2}{*}{ Location } & \multirow[t]{2}{*}{ Pigs studied } & \multirow[t]{2}{*}{$\begin{array}{l}\text { Number } \\
\text { sampled }\end{array}$} & \multirow[t]{2}{*}{$\begin{array}{l}\text { Number (\%) } \\
\text { with ILI }\end{array}$} & \multicolumn{2}{|c|}{$\begin{array}{l}\text { Number (\%) with } \\
\text { serological evidence of } \\
\text { avian H9N2 infection }\end{array}$} & \multicolumn{2}{|c|}{$\begin{array}{l}\text { Number (\%) with } \\
\text { serological evidence of } \\
\text { avian H7N9 infection }\end{array}$} & \multicolumn{2}{|c|}{$\begin{array}{l}\text { Number (\%) with } \\
\text { serological evidence of } \\
\text { H1N1 pdm09 infection }\end{array}$} \\
\hline & & & & $\begin{array}{l}\mathrm{HI} \text { assay } \\
\geq 1: 20\end{array}$ & $\begin{array}{l}\text { MN assay } \\
\geq 1: 80\end{array}$ & $\begin{array}{l}\text { HI assay } \\
\geq 1: 20\end{array}$ & $\begin{array}{l}\text { MN assay } \\
\geq 1: 80\end{array}$ & $\begin{array}{l}\text { HI assay } \\
\geq 1: 20\end{array}$ & $\begin{array}{l}\text { MN assay } \\
\geq 1: 80\end{array}$ \\
\hline \multirow[t]{3}{*}{ Jiangsu } & Weaning pigs & 84 & 18(21.4) & $8(9.5)$ & $4(4.8)$ & $0(0)$ & $0(0)$ & $22(26.2)$ & $14(16.7)$ \\
\hline & Finishing pigs & 120 & $12(10)$ & 14(11.7) & $8(6.7)$ & $2(1.7)$ & $0(0)$ & $48(40.0)$ & $22(18.3)$ \\
\hline & Sows & 92 & 12(13.0) & 18(19.5) & 12(13.0) & $4(4.3)$ & $0(0)$ & $28(30.4)$ & 18(19.6) \\
\hline \multirow[t]{3}{*}{ Zhejiang } & Weaning pigs & 92 & 10(10.9) & $6(6.5)$ & $2(2.2)$ & $0(0)$ & $0(0)$ & $34(37.0)$ & 10(10.9) \\
\hline & Finishing pigs & 124 & $20(16.1)$ & 14(11.3) & $8(6.5)$ & $0(0)$ & $0(0)$ & $40(32.3)$ & $26(21.0)$ \\
\hline & Sows & 108 & 18(16.7) & $24(22.2)$ & 16(14.8) & $4(3.7)$ & $0(0)$ & $40(37.0)$ & $20(18.5)$ \\
\hline \multirow[t]{3}{*}{ Guangdong } & Weaning pigs & 152 & $22(14.5)$ & 10(6.6) & $4(2.6)$ & $0(0)$ & $0(0)$ & $50(32.9)$ & $16(10.5)$ \\
\hline & Finishing pigs & 124 & $8(6.5)$ & 16(12.9) & $12(9.7)$ & $2(1.6)$ & $0(0)$ & $36(45.2)$ & $28(22.6)$ \\
\hline & Sows & 152 & 24(15.8) & $32(21.1)$ & $26(17.1)$ & $8(5.3)$ & $0(0)$ & $66(43.4)$ & $36(23.7)$ \\
\hline \multirow[t]{3}{*}{ Fujian } & Weaning pigs & 78 & 14(17.8) & $6(7.7)$ & $4(5.1)$ & $0(0)$ & $0(0)$ & $26(33.3)$ & 10(12.8) \\
\hline & Finishing pigs & 94 & $6(6.4)$ & $12(12.8)$ & $6(6.4)$ & $4(4.3)$ & $0(0)$ & $36(38.3)$ & 18(19.1) \\
\hline & Sows & 90 & $8(8.9)$ & 18(20.0) & 10(11.1) & $2(2.2)$ & $0(0)$ & $38(42.2)$ & $20(22.2)$ \\
\hline Total & & 1310 & $172(13.3)$ & 178(13.6) & $112(8.5)$ & $26(2.0)$ & $0(0)$ & $464(35.4)$ & $238(18.2)$ \\
\hline
\end{tabular}

$\mathrm{ILI}=$ influenza-like-illness; $\mathrm{HI}=$ horse RBC hemagglutination inhibition assay; $\mathrm{MN}=$ microneutralization assay; H9N2 = A/chicken/Guangdong/V/2008(H9N2); H1N1 = A/California/7/2009pandemic (H1N1); H7N9 = A/Guangdong/GH074/2013(H7N9).

elevated antibodies against avian influenza virus H7N9, and finishing pigs had increased risk (though not significant), compared to weaning pigs. Also, pigs without signs of influenza-like-illness had a significant increased risk of elevated antibodies to avian H9N2 and pdm09 H1N1 as compared to pigs with signs of influenza-like- illness. Influenza-like-illness had no significant effect on antibodies against H7N9 virus (Table 2). HI geometric mean antibody titers (GMT) of AIV H9N2 and H1N1 pdm09 were 33.44 and 40.98 respectively (Figure 1 ). The GMT of H7N9 was 22.25, indicating again that all serum samples were negative.

Table 2 Risk factors for elevated antibody against influenza A viruses by horse RBC hemagglutination inhibition assay (titer $\geq 1: 20$ ) among pigs sampled in Jiangsu , Zhejiang , Guangdong and Fujian Provinces China

\begin{tabular}{|c|c|c|c|c|c|c|}
\hline \multirow[b]{2}{*}{ Risk factor } & \multicolumn{2}{|c|}{ A/chicken/Guangdong/V/2008(H9N2) } & \multicolumn{2}{|c|}{ A/Guangdong/GH074/2013(H7N9) } & \multicolumn{2}{|c|}{ A/California/7/2009pandemic (H1N1) } \\
\hline & Number (\%) & OR $(95 \% \mathrm{Cl})$ & Number (\%) & OR $(95 \% \mathrm{Cl})$ & Number (\%) & OR $(95 \% \mathrm{Cl})$ \\
\hline \multicolumn{7}{|l|}{ Location } \\
\hline Jiangsu & $40(13.5)$ & $1.0[0.63-1.58]$ & $6(2.0)$ & $1.7[0.46-5.93]$ & 98(33.1) & $0.92[0.65-1.27]$ \\
\hline Fujian & $36(13.7)$ & $1.0[0.63-1.63]$ & $6(2.3)$ & $1.9[0.52-6.72]$ & 100(38.2) & $1.1[0.81-1.59]$ \\
\hline Guangdong & $58(13.6)$ & $1.0[0.65-1.52]$ & $10(2.3)$ & $1.9[0.59-6.16]$ & $152(29.2)$ & $1.0[0.75-1.37]$ \\
\hline Zhejiang & $44(13.6)$ & reference & $4(1.2)$ & reference & 114(35.2) & reference \\
\hline \multicolumn{7}{|l|}{ Pigs studied } \\
\hline Sows & $92(20.8)$ & $3.3[2.13-5.10]$ & $18(4.1)$ & $35.4[2.13-590.30]$ & 172(38.9) & $1.3[0.10-1.75]$ \\
\hline Finishing pigs & $56(12.1)$ & $1.7[1.09-2.75]$ & $8(1.7)$ & $15.2[0.84-264.4]$ & 160(34.6) & $1.0[0.83-1.46]$ \\
\hline Weaning pigs & $30(7.4)$ & reference & $0(0.0)$ & reference & 132(32.5) & reference \\
\hline \multicolumn{7}{|l|}{ Time } \\
\hline 2012 & 103(17.7) & $1.4[0.98-1.87]$ & $20(3.4)$ & $3.2[1.28-8.07]$ & 252(43.3) & $1.2[0.95-1.54]$ \\
\hline 2011 & 75(13.7) & reference & $6(1.1)$ & reference & 212(38.7) & reference \\
\hline \multicolumn{7}{|l|}{ ILI } \\
\hline No & 170(14.9) & $3.6[1.74-7.46]$ & $24(2.1)$ & $1.8[0.43-7.82]$ & $390(34.3)$ & $3.9[2.49-6.08]$ \\
\hline Yes & $8(4.6)$ & reference & $2(1.2)$ & reference & $24(14.0)$ & reference \\
\hline
\end{tabular}

Pigs were studied during the period January 2011 to November 2012. 


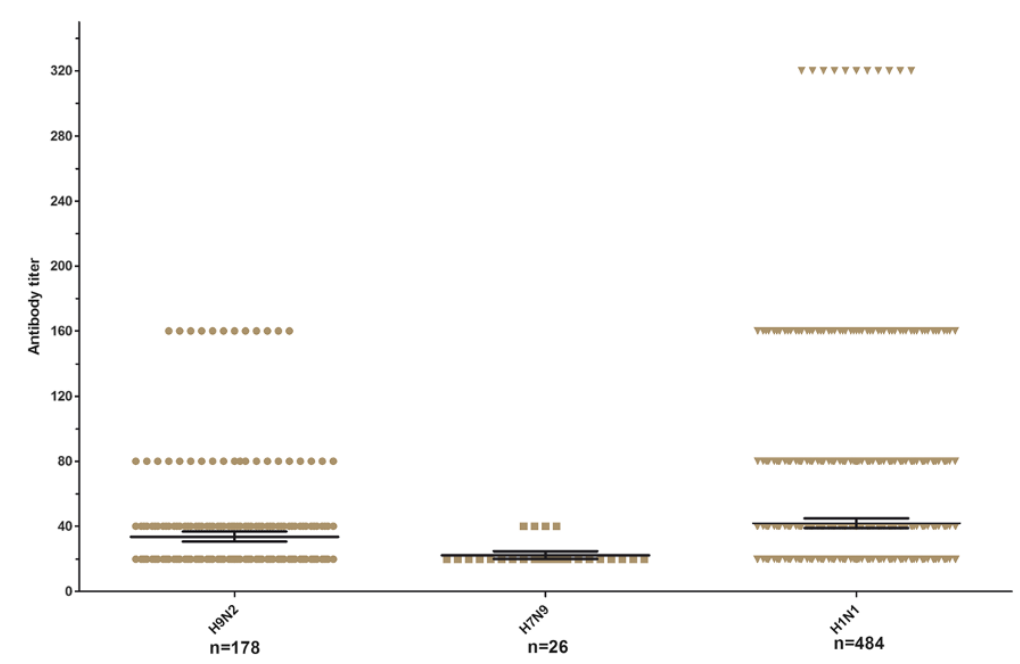

Figure 1 The geometric mean antibody titers of H9N2 AIV, H7N9 AIV and H1N1 pdm09 infections from January 2011 to November 2012 using a hemagglutination inhibition (HI) assay. Geometric mean titers and 95\% Cls of antibody titers against subtype H9N2, H7N9 and H1N1 are indicated by long and black short horizontal lines. Samples titers indicated by borrow symbols.

\section{Discussion}

China has been identified as a hot spot for the generation of novel influenza viruses. In this report, we identified large farms that seemed to have a high probability of exposure to the novel H7N9 virus and found no evidence of infection in pigs. The surveillance of pigs has focused on the subtype of H1, H3, H5 and H9 [11-13], while prior to the recent zoonosis of H7N9 [1,3-5,14,15], there were very few studies on the seroprevalence of the H7 subtype. Our results matched the results reported previously, with an $8.5 \%$ prevalence of $\mathrm{H} 9$ infection. Although we found no definitive serological evidence of avian $\mathrm{H} 7$ influenza virus in swine in southern China, 2.0\% of the specimens had an HI titer $\geq 1: 20$. This suggests that pig herds of southern China may have some potential risks of subtype $\mathrm{H} 7$ infection. While we agree that pigs have potential to serve as mixing vessels for the novel influenza virus generation $[16,17]$, this study found no evidence that pigs were involved in the ecology of the H7N9 virus.

Our study had a number of limitations. First, it is possible that results may have been confounded due to serologic cross-reactivity between different viral subtypes. In our study, the possibility of cross-reaction between subtypes was not evaluated. However, there were no positive serum against H7N9 via two serological methods ( $\mathrm{HI}$ and $\mathrm{MN}$ ), which indicates that no crossreaction occurred between $\mathrm{H} 7 \mathrm{~N} 9$ and other avian viruses of this study. Second, we did not study pigs from small farms or slaughterhouses, and thus our study population may not be representative of all pigs in these provinces.

\section{Conclusions}

The unique environment on swine farms and live animal markets (LAMs) in southern China provides many opportunities for wild aquatic birds, domestic poultry, and pigs to come in close contact with one another, thereby increasing the likelihood of interspecies transmission and generation of novel influenza viruses through reassortment $[11,18]$. As novel viruses may change rapidly, it seems prudent to continue surveillance for the H7N9 virus among non-poultry domestic animal species such as pigs and dogs $[19,20]$. Zhu et al. reported that pigs were infected productively by human-isolated H7N9 influenza virus and shed virus for 6 days [15]. $\mathrm{Xu}$ and colleagues reported rapid adaptation of avian H7N9 virus in pigs; the avian $\mathrm{H} 7 \mathrm{~N} 9$ virus replicated to a high titer after only one passage [14]. P. Horby suggests that a hidden epidemic of H7N9 in other animals may be well under way and that it will provide opportunities for further adaptation of H7N9 to mammals and for re-assortment with human- or pigadapted viruses if H7N9 is circulating in the large populations of pigs [21]. Therefore, such studies are crucial in understanding and reducing risk factors for human H7N9 infection in China.

\section{Ethical approval}

This study protocol was reviewed and approved by the Institutional Review Board of South China Agricultural University.

\section{Competing interests}

The authors declare that they have no competing interests.

\section{Authors' contributions}

$\mathrm{PZ}$ and $\mathrm{GZ}$ designed the experiments. $\mathrm{MH}, \mathrm{LW}, \mathrm{HH}$ carried out the tests. PZ, MMM and LS drafted the manuscript. All authors have read and approved the final manuscript.

\section{Acknowledgements}

We thank Professor Gregory C. Gray of Duke Medicine and Duke-NUS for his helpful critical review of this manuscript. 


\section{Funding}

This work was supported by the National Key Basic Research Program (Project 973) of China (grant no. 2011CB504700-G), the Science and Technology Projects of Guangdong province (2012B020306005), the International Sci \& Tech Cooperation Program (2010DFB33920) and the Modern Agricultural Industry Technology System (CARS-36). The funding organizations had no role in the study design, data collection and analysis, ownership of the materials, or preparation of the manuscript.

\section{Author details}

'Key Laboratory of Animal Disease Control and Prevention of the Ministry of Agriculture, College of Veterinary Medicine, South China Agricultural University, 483 Wushan Road, Tianhe District, Guangzhou 510642, China. ${ }^{2}$ Department of Environmental \& Global Health, College of Public Health \& Health Professions, University of Florida, 101 S. Newell Dr, Gainesville, FL 32610, USA.

Received: 24 May 2014 Accepted: 20 August 2014

Published: 2 September 2014

\section{References}

1. Gao R, Cao B, Hu Y, Feng Z, Wang D, Hu W, Chen J, Jie Z, Qiu H, Xu K, Xu X, Lu H, Zhu W, Gao Z, Xiang N, Shen Y, He Z, Gu Y, Zhang Z, Yang Y, Zhao X, Zhou L, Li X, Zou S, Zhang Y, Li X, Yang L, Guo J, Dong J, Li Q, et al: Human infection with a novel avian-origin influenza $\mathrm{A}$ (H7N9) virus. N Engl J Med 2013, 368(20):1888-1897.

2. WHO: Avian influenza A(H7N9) virus. 2013. http://www.who.int/influenza/ human_animal_interface/influenza_h7n9/en/index.html?treeid = BEAC9C103DF952C104\&nowtreeid $=$ 109A124F107E106CF505AA103.

3. Zhang Q, Shi J, Deng G, Guo J, Zeng X, He X, Kong H, Gu C, Li X, Liu J, Wang G, Chen Y, Liu L, Liang L, Li Y, Fan J, Wang J, Li W, Guan L, Li Q, Yang $H$, Chen $P$, Jiang $L$, Guan $Y$, Xin X, Jiang $Y$, Tian G, Wang X, Qiao C, Li C, et al: H7N9 influenza viruses are transmissible in ferrets by respiratory droplet. Science 2013, 341(6144):410-414.

4. Gabbard JD, Dlugolenski D, Van Riel D, Marshall N, Galloway SE, Howerth EW, Campbell PJ, Jones C, Johnson S, Byrd-Leotis L, Steinhauer DA, Kuiken T, Tompkins S, Tompkins SM, Tripp R, Lowen AC, Steel J: Novel H7N9 Influenza Virus Shows Low Infectious Dose, High Growth Rate, and Efficient Contact Transmission in the Guinea Pig Model. J Virol 2014 88(3):1502-1512

5. Watanabe T, Kiso M, Fukuyama S, Nakajima N, Imai M, Yamada S, Murakami S, Yamayoshi S, Iwatsuki-Horimoto K, Sakoda Y, Takashita E, McBride R, Noda T, Hatta M, Imai H, Zhao D, Kishida N, Shirakura M, de Vries RP, Shichinohe S, Okamatsu M, Tamura T, Tomita Y, Fujimoto N, Goto K, Katsura H, Kawakami E, Ishikawa I, Watanabe S, Ito M, et al: Characterization of H7N9 influenza A viruses isolated from humans. Nature 2013, 501(7468):551-555.

6. OIE: Low pathogenic avian influenza (poultry), China (People's Rep. of). 2013. Available at: http://www.oie.int/wahis_2/public/wahid.php/Reviewreport/ Review?reportid=13314.

7. Kwon TY, Lee SS, Kim CY, Shin JY, Sunwoo SY, Lyoo YS: Genetic characterization of $\mathrm{H} 7 \mathrm{~N} 2$ influenza virus isolated from pigs. Vet Microbiol 2011, 153(3-4):393-397.

8. Green A: The epidemiologic approach to studies of association between HLA and disease: II. Estimation of absolute risks, etiologic and preventive fraction. Tissue Antigens 1982, 19:259-268.

9. Tian J, Qi W, Li X, He J, Jiao P, Zhang C, Liu GQ, Liao M: A single E627K mutation in the PB2 protein of H9N2 avian influenza virus increases virulence by inducing higher glucocorticoids (GCs) level. PLoS One 2012, 7(6):e38233.

10. WHO: Manual for the laboratory diagnosis and virological surveillance of influenza. 2011. Available at: http://www.aitoolkit.org/site/DefaultSite/ filesystem/documents/WHO\%20lab\%20manual.pdf.

11. Ninomiya A, Takada A, Okazaki K, Shortridge KF, Kida H: Seroepidemiological evidence of avian $\mathrm{H} 4, \mathrm{H} 5$, and $\mathrm{H} 9$ influenza A virus transmission to pigs in southeastern China. Vet Microbiol 2002, 88(2):107-114

12. $L i H Y$, Yu KZ, Xin XG, Yang HL, Li YB, Qin YN, Bi YZ, Tong GZ, Chen HL: Serological and virologic surveillance of swine influenza in China from 2000 to 2003. Int Congr Ser 2004, 1263:754-757.

13. Song XH, Xiao H, Huang Y, Fu G, Jiang B, Kitamura Y, Liu W, Liu D, Gao GF: Serological Surveillance of Influenza A Virus Infection in Swine
Populations in Fujian Province, China: No Evidence of Naturally Occurring H5N1 Infection in Pigs. Zoonoses Public Health 2010, 57(4):291-298.

14. Xu L, Bao L, Deng W, Zhu H, Li F, Chen T, Lv Q, Yuan J, Xu Y, Li Y, Yao Y, Gu S, Yu P, Chen H, Qin C: Rapid adaptation of avian H7N9 virus in pigs. Virology 2014, 452-453:231-236.

15. Zhu H, Wang D, Kelvin DJ, Li L, Zheng Z, Yoon SW, Wong SS, Farooqui A, Wang J, Banner D, Chen R, Zheng R, Zhou J, Zhang Y, Hong W, Dong W, Cai Q, Roehrl MH, Huang SS, Kelvin AA, Yao T, Zhou B, Chen X, Leung GM, Poon LL, Webster RG, Webby RJ, Peiris JS, Guan Y, Shu Y, et al: Infectivity, transmission, and pathology of human-isolated H7N9 influenza virus in ferrets and pigs. Science 2013, 341(6142):183-186.

16. Brown $\mathrm{H}$ : The epidemiology and evolution of influenza viruses in pigs. Vet Microbiol 2000, 74(1-2):29-46.

17. Su S, Qi WB, Chen JD, Zhu WJ, Huang Z, Xie JX, Zhang GH: Seroepidemiological Evidence of Avian Influenza A Virus Transmission to Pigs in Southern China. J Clin Microbiol 2013, 51(2):601-602.

18. Zhang G, Kong W, Qi W, Long LP, Cao Z, Huang L, Qi H, Cao N, Wang W, Zhao F, Ning Z, Liao M, Wan XF: Identification of an H6N6 swine influenza virus in southern China. Infect Genet Evol 2011, 11(5):1174-1177.

19. Su S, Zhou P, Fu X, Wang L, Hong M, Lu G, Sun L, Qi W, Ning Z, Jia K, Yuan Z, Wang H, Ke C, Wu J, Zhang G, Gray GC, Li S: Virological and epidemiological evidence of avian influenza virus infections among feral dogs in live poultry markets, china: a threat to human health? Clin Infect Dis 2014, 58(11):1644-1646.

20. Su S, Gray GC, Lu J, Liao M, Zhang G, Li S: New "One Health" Strategies Needed for Emerging Pathogens Detection and Control at Cantonese Live Animal Markets, China. Clin Infect Dis 2014, [Epub ahead of print].

21. Horby P: H7N9 is a virus worth worrying about. Nature 2013, 496(7446):399-399.

doi:10.1186/s12917-014-0203-x

Cite this article as: Zhou et al:: Serological report of influenza a (H7N9) infections among pigs in Southern China. BMC Veterinary Research 2014 10:203.

\section{Submit your next manuscript to BioMed Central and take full advantage of:}

- Convenient online submission

- Thorough peer review

- No space constraints or color figure charges

- Immediate publication on acceptance

- Inclusion in PubMed, CAS, Scopus and Google Scholar

- Research which is freely available for redistribution 